\title{
Prof. MUDr. Karel Opatrný Jr., DrSc.
}

June 4, 1954 to March 9, 2006

Professor Karel Opatrný graduated from Charles University School of Medicine in Pilsen in 1979. He started his medical career at the Department of Medicine I in Pilsen. In 1990, he went to work in the Prague-based Strahov Medical Department, a center of international renown, where he earned his $\mathrm{PhD}$ degree and served as its head in 1992-1994. He returned to Pilsen in 1994 to take up his position as Head of Department of Medicine I. Professor Opatrný earned a DSc degree, becoming a professor in internal medicine and a generally recognized personality, both as a professional and an individuality. He climbed the pyramid of scientific and pedagogic degrees as young as 46 .

His personality was a unique combination of talent and diligence, and one setting extreme demands not only on himself but also on his colleagues. Still, I have no doubt everybody was happy to be able to work with him, certainly the best certificate for the head of a department.

Professor Opatrný's main scientific interest was dialysis membrane biocompatibility, a topic he presented and published a number of papers at local and international forums, and organized several international conferences on the topic. He published his findings in an exquisite monograph entitled 'Dialysis membrane biocompatibili$t y$ '. Recently, Professor Opatrný had focused his attention on proteomics. He became familiar with this new specialty while visiting the USA (University of Louisville). When back in the Czech Republic, Prof. Opatrný was able to set up a top laboratory initiating research into priority projects in this field. At the same time, he became the chief investigator of a major research project of the Czech Health Ministry, certainly a token of recognition of Prof Opatrný as an investigator and the Medical School in Pilsen. The research project significantly continues to

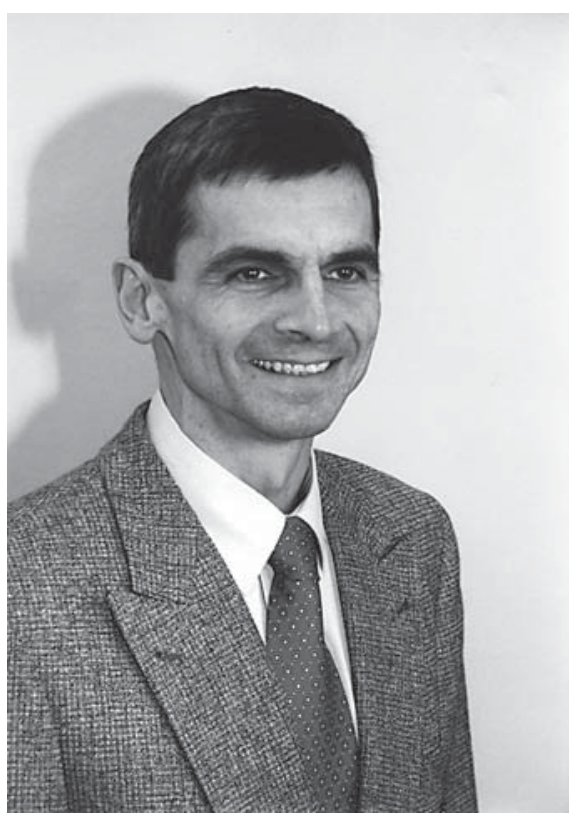

promote science at the School of Medicine in Pilsen and not only in the field on nephrology.

Sadly enough, he was not able to complete his research projects.

The number of Prof. Opatrný's publications is 314 ; he presented some 280 lectures at national and international congresses, often as an invited speaker. A list of his activities and positions in university, faculty, international and other institutions is beyond the scope of this article. Let us mention, just as examples: Vice Dean for Science, Education, and International Relations of Charles University in Prague, Medical School based in Pilsen; member and, later, Vice President of the Board of the

\begin{tabular}{ll}
\hline KARGER & ( 2006 S. Karger AG, Basel \\
Fax +4161306 12 34 & ac53-5068/06/0246-0583\$23.50/0 \\
$\begin{array}{l}\text { E-Mail karger@karger.ch } \\
\text { www.karger.com }\end{array}$ & $\begin{array}{l}\text { Accessible online at: } \\
\text { www.karger.com/bpu }\end{array}$
\end{tabular}


Czech Society of Nephrology, member of the Scientific Board of the Czech Ministry of Health, member of the Evaluation Committee for Reviewing and Assessing of the Scientific Activities of Faculties and Parts of Charles University; presidency and membership in organizing committees of conferences of nephrology in the Czech Republic, in Vienna, and in Nagoya, Editor-in Chief of Current Issues in Nephrology, Czech nephrology journal, membership in Editorial Boards of international journals (Blood Purification, Kidney and Blood Pressure Research,
Nieren- und Hochdruckkrankheiten), membership in examination boards in internal medicine and nephrology.

I do not think one could manage to do more in one's lifetime.

Sadly, international and Czech nephrology, science and patients will only refer to Professor Opatrný in the preterite tense. Still, one should not use many words when remembering a distinguished person.

Professor Karel Matoušovic Prague, June 2006 